GOLOVNYA Olena - Doctor of Economic Sciences, Associate Professor of the Department of International Management, Hotel and Restaurant Business and Tourism, Vinnytsia National Agrarian University (21008, Vinnytsia, 3, Soniachna Str., e-mail: ellens@ @eta.ua).

KONDRATOVA Maryna - Candidate of Pedagogical Sciences, Director of the Separate Structural Subdivision «Nemyriv Professional College of Construction, Economics and Design of Vinnytsia National Agrarian University» (22800, Nemyriv, 29, Gymnasium Str., e-mail: kondratovamarina960@gmail.com).

ГОЛОВНЯ Елена Михайловна - доктор экономических наук, доцент кафедры менеджмента внешнеэкономической деятельности, гостиничноресторанного дела и туризма, Винницкий национальный аграрный университет (21008, г. Винница, ул. Солнечная, 3, e-mail: ellens@ meta.ua).

КОНДРАТОВА Марина Владимировна - кандидат педагогических наук, директор Обособленного структурного подразделения «Немировский профессиональный колледж строительства, экономики и дизайна Винницкого национального аграрного университета» $(22800$, г. Немиров, ул. Гимназическая, 29, e-mail: kondratovamarina960@gmail.com).

УДК 004:338.488.2:640.43

DOI: 10.37128/2411-4413-2021-3-13

\section{ДІДЖИТАЛІЗАЦІЯ ЯК ОСНОВНИЙ ФАКТОР РОЗВИТКУ ІНДУСТРІї ГОСТИННОСТІ У KPAÏHAX ЄВРОСОЮЗУ}

ДЖЕДЖУЛА О.М., доктор педагогічних наук, професор, завідувачка кафедри математики та інформаційних технологій

ВОЛОНТИР Л.О., кандидат технічних наук, доцент кафедри комп'ютерних наук та економічної кібернетики, Вінницький національний аграрний університет (м. Вінниця)

У статті розглянуто основні тенденщії розвитку ринку індустрії гостинності у краӥнах Євросоюзу. Аналітичний огляд наукових джерел дозволив виокремити серед них такі: поглиблення спеціалізації готельної ци ресторанної пропозицій; створення міжнародних готельних $i$ ресторанних ланцюгів; розвиток мережі малих підприємств; впровадження в індустрію гостинності нових комп'ютерних технологій; підготовка висококваліфікованого персоналу. Гостра потреба в інноваціях актуалізує проблему впровадження в індустрію гостинності нових комп'ютерних технологій та відповідної підготовки висококваліфікованого персоналу. Визначено основні напрями діджиталізачіі як основи інновацій в індустрію гостинності: технології розпізнавання образів (облич), використання роботів, віртуальні компаньйони, обладнання номерів "розумною» технікою, використання модулів типу «Онлайн супермаркет турів». Запропоновано класифікацію світових інновацій у готельному бізнесі за видами, нововведеннями та значенням для розвитку гостинного бізнесу. Серед інновацій виокремлено інформаційні та маркетингові 
види. Інновачії інформаційного характеру пов'язані з хмарною системою автоматизаиіі готелів, хмарним сервісом для управління готелем, сервісом для бронювання готелів, створенням WOW-ефекту у клієнтів та ін. Проведено аналіз підготовки фахівиів для готельно-ресторанного бізнесу у країнах Свропи, які здатні забезпечувати діджиталізацію бізнесу. Розглянуто особливості професійної підготовки менеджерів у вищій школі Швейщарії, яка посідає перше місие у топ-10 найкращих шкіл гостинності світу. На основі проведеного аналізу сформульовано рекомендачії для підготовки фахівців готельноресторанного бізнесу в Украӥні, які акиентують увагу на якісній практичній підготовиі студентів шляхом тривалого стажування у провідних готелях України та за кордоном, залученні майбутніх фахівців до роботи над інноваційними проєктами, створенні в університетах високотехнологічних навчальних середовищ.

Ключові слова: ринок індустрії гостинності, діджиталізація готельно-ресторанного бізнесу, інноваційна діяльність, «віртуальні компаньйони», «розумна» техніка, хмарна система автоматизації готелів.

Табл.: 3. Рис.: 1. Літ.: 13.

\title{
DIGITALIZATION AS THE MAIN FACTOR OF DEVELOPMENT OF THE HOSPITALITY INDUSTRY IN THE EU COUNTRIES
}

\author{
DZHEDZHULA Olena, \\ Doctor of Pedagogical Sciences, Professor, \\ Head of the Department of Mathematics, \\ Physics and Computer Technologies \\ VOLONTYR Lyudmyla, \\ Candidate of Technical Sciences, Associate Professor \\ of the Department of Computer Science and Economic Cybernetics, \\ Vinnytsia National Agrarian University \\ (Vinnytsia)
}

The article considers the main trends in the development of the hospitality industry market in the European Union. The analytical review of scientific sources allowed to single out among them the following: deepening of specialization of hotel and restaurant offers; creation of international hotel and restaurant chains; development of a network of small enterprises; introduction of new computer technologies in the hospitality industry; training of highly qualified personnel. The contradiction between the urgent need for innovation in the hospitality business highlights the problem of introduction of new computer technologies in the hospitality industry and the appropriate training of highly qualified personnel. The main directions of digitalization as the basis of innovations introduced in the hospitality industry are determined: technologies of pattern recognition (face); use of robots, virtual companions, equipment of rooms with «smart» equipment, use of modules such as "Online supermarket tours». The classification of world innovations in the hotel business by types, innovations and significance for the development of the hospitality business is offered. Among the innovations are informational and marketing types. Informational innovations are related to the Cloud Hotel Automation System, the Cloud Hotel Management Service, the Hotel Booking Service, the creation of a WOW-effect for customers, etc. An analysis of the training of specialists for the hotel and restaurant business in European countries that are able to ensure the digitalization of the hospitality business is conducted. The peculiarities of professional training of managers in higher education in Switzerland, which ranks first in the top 10 of best hospitality schools in the world, are considered. Due to the analysis, recommendations are formulated for the training of the specialists of hotel and restaurant business in Ukraine, which focus on quality of 
practical training of students through long internships in leading hotels in Ukraine and abroad, attracting future professionals to work on innovative projects, creating high-tech learning environments in universities.

Key words: hospitality industry market, digitalization of hospitality business, innovative activity, «virtual companions», «smart» technology, cloud hotel automation system.

Table: 3. Fig.: 1. Ref.: 13.

\title{
ДИДЖИТАЛИЗАЦИЯ КАК ОСНОВНОЙ ФАКТОР РАЗВИТИЯ ИНДУСТРИИ ГОСТЕПРИИМСТВА В СТРАНАХ ЕВРОСОЮЗА
}

\author{
ДЖЕДЖУЛА Е.M., \\ доктор педагогических наук, профессор, \\ заведующая кафедрой математики, \\ физики и компьютерных технологий \\ ВОЛОНТЫР Л.О. \\ кандидат технических наук, доцент \\ кафедры компьютерных наук и экономической кибернетики, \\ Винницкий национальный аграрный университет
} (2. Винница).

B cтатье рассмотрены основнье тенденции развития рынка индустрии гостеприимства в странах Евросоюза. Аналитический обзор научных источников позволил выделить среди них: углубление специализации гостиничного и ресторанного предложения; создание международных гостиничных и ресторанных иепей; развитие сети мальх предприятий; внедрение в индустрию гостеприимства новых компьютерных технологий; подготовка высококвалифицированного персонала. Острая потребность в инновациях актуализирует проблему внедрения в индустрию гостеприимства новых компьютерных технологий и соответствующей подготовки высококвалифицированного персонала. Определены основные направления диджитализации как основы внедрения инноваций в индустрию гостеприимства: технологии распознавания образов (лии), использование роботов, виртуальные компаньоны, оборудование номеров «умной» техникой, использование модулей типа «Онлайн супермаркет туров». Предложена классификация мировых инноваций в гостиничном бизнесе по видам, нововведениям и значению для развития гостиничного бизнеса. Среди инноваций выделены информационные и маркетинговые виды. Инновачии информачионного характера связаны с облачной системой автоматизаџии гостинии, облачным сервисом управления гостиницей, сервисом для бронирования отелей, созданием WOW-эффекта для клиентов и др. Проведен анализ подготовки специалистов для гостинично-ресторанного бизнеса в странах Европы, способных обеспечивать диджитализацию бизнеса. Рассмотрень особенности профессиональной подготовки менеджеров в высшей школе Швейцарии, которая занимает первое место в топ-10 лучших школ гостеприимства мира. На основе проведенного анализа сформулированы рекомендации для подготовки специалистов гостинично-ресторанного бизнеса в Украине, которые акцентируют внимание на качественной практической подготовке студентов путем длительной стажировки в ведущих отелях Украины и за рубежом, привлечением будущих специалистов к работе над инновационными проектами, созданием в университетах высокотехнологических учебных сред.

Ключевые слова: рынок индустрии гостеприимства, диджитализация гостиничноресторанного бизнеса, инновационная деятельность, «виртуальные компаньоны», «умная» техника, облачная система автоматизации гостиниц.

Табл.: 3. Рис.: 1. Лит.: 13. 
Постановка проблеми. Категорія «гостинність» є однією із важливих та фундаментальних вимірів людської цивілізації. Українські та зарубіжні науковці приділяють значну увагу дефінітивному аналізу поняття гостинності $[1,5,11]$.

Гостинність походить від англійського «hospitality». Індустрію гостинності розглядають як поєднання готельно-ресторанного та туристичного бізнесу [3, с. 97]. Як зазначено у дослідженнях Ставської Ю.В. [10, с. 36], Табенської O.I. [11, с. 185-186], визначальною є орієнтація на клієнта, а саме задоволення його потреб та створення комфортного емоційного стану.

Як будь-який інший вид бізнесу, гостинна індустрія має за мету отримання максимального прибутку від надання послуг проживання, харчування, розважального та транспортних сервісів.

Основна функція індустрії гостинності полягає у задоволенні потреб у матеріальних та нематеріальних послугах, забезпечення людини повноцінним i комфортним відпочинком за доступними цінами. За цих умов важливим фактором є захист та безпека навколишнього середовища.

Індустрія гостинності належить до галузей світового господарства. Ї̈ї розвиток $\epsilon$ досить динамічним, що забезпечує зайнятість працездатного населення, дає значний внесок до валового внутрішнього продукту національних економік. Сьогодні в умовах пандемії в індустрії гостинності відбуваються трансформації, пов'язані з впровадженням нових технологій у бізнес-процеси. Економічний ефект функціонування індустрії гостинності формується розвитком сфери дозвілля та створенням комплексу соціальнопобутової інфраструктури, яка відіграє одну 3 головних ролей у світовій економіці.

Таким чином, розвиток індустрії гостинності $\epsilon$ актуальним для національних економік країн світу та набуває особливостей в умовах інформатизації суспільства. Ця галузь має невикористаний потенціал для покращення соціально-економічного розвитку держави, оскільки готельноресторанний та туристичний бізнес пов'язаний із десятками суміжних галузей, які сприяють створенню додаткових робочих місць. Зазначимо, що в Україні індустрія гостинності менш розвинена у порівнянні з міжнародною спільнотою, що викликає потребу у дослідженні основних трендів іiі розвитку у країнах Євросоюзу з метою впровадження позитивного досвіду в економіку нашої країни. Частка туристичного бізнесу у структурі національних економік країн Європи є значною, безпосередньо залежить від розвитку готельно-ресторанного бізнесу та приносить значний економічний ефект.

Аналіз останніх досліджень і публікацій. Організаційні та економічні проблеми розвитку індустрії гостинності, зокрема готелів і ресторанів, $\epsilon$ предметом досліджень багатьох вітчизняних науковців, серед яких Гросул В.А. [2], Дишкантюк О.В. [3], Кузьменко А.В. [5], Косенко А.В. [8], Найдюк В.С. [7], Нездоймінов С.Г., Дишловий І.М. [6], Попик М.М. [9] та інші, які розкривають сутність проблемних питань та пропонують шляхи їх 
вирішення. Важливими є результати дослідження зарубіжного досвіду розвитку підприємницьких структур та можливості його використання в Україні, проведеного Гончарук Т.В. [1].

Перспективи та тенденції розвитку готельно-ресторанного бізнесу України, аналіз його інноваційної діяльності розглянуто у працях українських учених Юрчук Н.П. [12], Маслака М.В., Матросова В.О. [8] та ін.

Досвід ЄС та інших країн свідчить про стрімке впровадження нововведень у бізнес-процеси готельно-ресторанної сфери і обумовлює необхідність детального вивчення і систематизації.

Формулювання цілей статті. Метою статті $є$ досліження основних тенденцій розвитку індустрії гостинності у країнах Свропи в умовах діджиталізації суспільства.

Виклад основного матеріалу дослідження. Вивчаючи сучасні тенденції розвитку індустрії гостинності у країнах Євросоюзу, можна виділити наступні:

1) поглиблення спеціалізації готельної й ресторанної пропозицій;

2) створення міжнародних готельних і ресторанних ланцюгів;

3) розвиток мережі малих підприємств;

4) впровадження в індустрію гостинності нових комп'ютерних технологій;

5) підготовка висококваліфікованого персоналу [4].

Розглянемо більш детально кожну позицію.

У готельному господарстві спеціалізація дозволяє поглибити орієнтацію на обслуговування певних споживачів послуг індустрії гостинності, оскільки постійно розширюються та змінюються цілі поїздок. Поглиблення спеціалізації формує основні характеристики готельних послуг: ціну на послуги, місце розташування підприємства, комфортність номерного фонду, оснащеність номерів тощо.

Посилення спеціалізації готельного бізнесу дозволяє не лише орієнтуватись на певні сегменти споживачів, але й враховувати різні запити клієнтів та формувати більш специфічний перелік послуг. Так, із урахуванням цінового рівня, чітко позначилися три сегменти: нижчий (бюджетний), середній (економічний) та вищий (люкс).

Спеціалізація також може проводитись за цілями поїздки: готель може бути зорієнтований на клієнтів, які беруть участь у конференціях, конгресах, проводять активний чи пасивний відпочинок та ін.; за віком; за видом трудової діяльності споживачів і за іншими ознаками. Головне завдання спеціалізованих підприємств полягає у створенні максимального задоволення і комфорту під час відпочинку.

Спеціалізація індустрії гостинності одночасно передбачає диверсифікацію, тобто освоєння нових видів послуг, які мають попит і $є$ привабливими 3 точки зору цінової політики за рахунок раціонального використання ресурсів. Сучасні готельні підприємства пропонують клієнтові згідно 3 попитом та ціною найбільш прийнятний варіант послуги, водночас 
інформують клієнтів про нові форми діяльності у цьому виді сервісу. Так, при спорудженні фешенебельних готелів та готелів середнього класу, сьогодні обов'язковими $\epsilon$ розважальні, спортивні, оздоровчі послуги, послуги гастрономічних закладів, наявність плавального басейну, фітнес-клубу, сауни, солярію, нічних клубів, косметичних салонів та інших закладів 3 надання додаткових послуг.

Поглиблення спеціалізації пропозиції послуг підприємств готельного господарства тісно пов'язано 3 такою важливою тенденцією, як створення міжнародних готельних ланцюгів.

Готельний ланцюг позначає об'єднання кількох готельних підприємств, управління яким здійснюється під одним керівництвом, у межах єдиної концепції просування продукту і під спільною торговельною маркою.

Історично склалися наступні способи об'єднання готелів у ланцюгах:

- будівництво та купівля підприємств готельною компанією;

- укладення договору франчайзингу;

- підписання контракту на управління.

Виділяють три основних моделі формування готельних ланцюгів: модель «Цезаря Рітца», «Кемонса Вілсона» та «Best Western».

У першій моделі основна ставка робиться на європейські традиції вишуканості й аристократизму. Сьогодні ця модель зазнала кризи.

Друга модель відрізняється більшою гнучкістю при задоволенні потреб клієнта у поєднанні 3 дотриманням високих стандартів обслуговування. Основними вимогами, за цих обставин, вважають єдність стилю (архітектура, інтер'єр), єдність позначень і зовнішньої інформації, просторий i функціональний хол, швидкість реєстрації клієнтів, номери для постійних клієнтів, сніданок «шведський стіл», наявність конференц-залу, гнучка система тарифів, єдине управління, маркетинг і служба комунікації.

Характерним для третьої моделі є об'єднання готелей під єдиною торговою маркою за однорідними ознаками, дотримання певних стандартів і надання певного набору послуг незалежно від країни розташування. Кожна складова ланцюга зберігає фінансово-економічну та управлінську самостійність.

Об'єднання підприємств у готельні ланцюги має наступні переваги:

- інтеграція стратегії продажів і маркетингових зусиль учасників ланцюгів за рахунок просування спільного бренда;

- розроблення і впровадження спільного логотипа й торгової марки. Застосування прямого маркетингу, просування бренда окремого готелю як компонента локального готельного ланцюга;

- участь у виставковій діяльності 3 централізованою презентацією учасників ланцюга;

- вивчення споживчих потреб та потенційного попиту для кожного окремо взятого готельного підприємства завдяки формуванню єдиних програм для постійного гостя, єдиних бонусних програм із авіалініями, єдиної 
пропозиції щодо пакетів послуг, спеціальних акцій і програм;

- створення комплексних програм лояльності споживачів за допомогою: управління каналами збуту, надання можливості користування єдиною корпоративно-договірною базою; оптимізації прибутковості номерного фонду за рахунок перегляду пакетного розміщення; оптимізації попиту за рахунок єдиного представлення i просування по каналах Інтернет-ресурсів; централізованої презентації у міжнародній комп'ютерній системі бронювання; централізованої презентації у туристичних каталогах, рекламно-інформаційних матеріалах;

- розроблення комплексних програм для оптимізації обороту й завантаження номерного фонду, а також інших послуг готельного підприємства на основі: впровадження єдиних підходів до ціноутворення готельних послуг; використання і розвитку єдиної клієнтської бази; презентації у глобальних системах бронювання на певних умовах; використання додаткових онлайнових каналів збуту; загального аналізу економічних показників i управління доходами;

- здійснення контролю за якістю реалізованих послуг ланцюговими готелями.

Використовують два основні види готельних ланцюгів: інтегровані ланцюги, які створені з однорідних одиниць, та готельні консорціуми, які об'єднують незалежні готелі. Інтегровані готельні ланцюги керуються безпосередньо або опосередковано через франчайзингову систему або за контрактом на управління. Усі готелі інтегрованого ланцюга мають спільну назву і товарний знак. Прикладом найбільш інтегрованих ланцюгів у Євросоюзі $\epsilon$ французька група «Аккор».

Щоб протистояти конкуренції з боку інтегрованих та франчайзингових готельних ланцюгів, незалежні готелі об’єднуються у готельні консорціуми. Концепція готельних консорціумів в останні роки набула популярності, їх кількість значно збільшилася. Масштаби діяльності за умови об'єднання у консорціум дозволяють досягати значної економії у витратах на маркетинг, придбання обладнання, створення комп'ютерних мереж бронювання місць тощо.

Найпоширенішою формою організації готельних ланцюгів $є$ франчайзинг. За визначенням Міжнародної організації франчайзингових організацій, франчайзинг - це спосіб ведення бізнесу, за якого провідний суб'єкт господарської діяльності надає передові технології та можливість функціонувати під його маркою іншим організаціям. Для підприємства франчайзинг означає реальну можливість ефективно розвивати бізнес, а для споживачів - гарантує високий рівень якості обслуговування.

За останні роки структура готельного господарства характеризується зміною типів підприємств, що належать до різних форм малого підприємництва.

Розвиток мережі малих підприємств обумовлений тим, що сьогодні сфера 
туризму на світовому рівні зазнає активного розвитку та формування нових напрямів. Паралельно з традиційними видами туризму набувають поширення усілякі нетрадиційні форми відпочинку та подорожей. Усе більший вплив на сферу туризму робить поширення ідей екологізації. У більшості країн Свропи заняття сільським туризмом заохочується на державному рівні, а це важлива мотивація для розвитку малих підприємств індустрії гостинності. Розвиток мережі малих підприємств пов'язаний із тим, що малі готельні підприємства краще адаптуються до вимог споживача, водночас створюючи приємну атмосферу для перебування гостей. Такі готелі користуються популярністю ще й тому, що є дешевшими та мають більш гнучку систему знижок.

Значний вплив на стан та перспективи розвитку гостинного бізнесу в Євросоюзі мають інформаційні технології та рівень підготовленості обслуговуючого персоналу. Тому розглянемо ці аспекти більш детально.

Інформатизоване суспільство має принципово нові потреби та можливості для життя і професійної діяльності людини. Бути в тренді останніх технологічних тенденцій важливо для тих, хто працює у готельно-ресторанній галузі, адже рівень конкуренції в ній є надзвичайно високим. Це означає, що ті, хто не може адаптуватися, можуть швидко виявити, що відстають від готельних та туристичних компаній, які впровадили нові підходи та ідеї.

Розглянемо декілька основних трендів діджиталізації, які впроваджені в індустрії гостинності:

1. Технологія розпізнавання. Індустрія гостинності має справу з великою кількістю клієнтів. Тому для власників готелів, авіакомпаній та інших компаній головним пріоритетом є проведення операцій із ними ефективно, швидко та безпечно. Це є ідеальним полем для впровадження технології розпізнавання образів (облич).

Системи розпізнавання образів можуть використовуватися для автоматизації процесів підтвердження чи авторизації під час подорожі клієнта. Можливість виявлення конкретних людей, навіть у великих групах, допомагає зробити системи безпеки більш надійними.

Наприклад, у двох різних готелях Marriott у Китаї гості тепер мають можливість обійти традиційну реєстрацію та натомість цього піти у спеціальний кіоск, де технологія розпізнавання сканує їх обличчя, ідентифікує і надає їм ключ-карту, і все це триває приблизно одну хвилину. Цей підхід стрімко поширюється в готелях країн Євросоюзу [12].

2. Використання роботів. Поява роботів $є$ важливою технологічною тенденцією. Багато компаній, які надають послуги у сфері гостинності, використовують їх. Мабуть, найвідоміший приклад цього - робот-консьєрж Хілтон «Конні», який використовує розпізнавання мови та штучний інтелект для відповіді на запитання гостей та вчиться на взаємодії 3 людьми, вдосконалюючи свої відповіді [4].

Роботи стали популярними в індустрії гостинності завдяки тому, що ідеї автоматизації та самообслуговування відіграють усе більшу роль у наш час. 
Використання роботів може призвести до покращення швидкості, економічності та точності обслуговування. У певних ситуаціях роботи можуть виконувати свою роботу з більшою точністю та послідовністю, ніж люди, і «Людський фактор» усувається. Роботи здатні виконувати небезпечну роботу, можуть бути запрограмовані на виконання роботи, яку людина не хотіла або не змогла б зробити.

3. Віртуальні компаньйони. Люди, котрі звикли до цифрових асистентів і чат-ботів, зацікавлені у віртуальних компаньйонах, які можуть бути корисними при навчанні, отриманні розваг та дружньому спілкуванні.

Сьогодні цифрові асистенти у готелях можуть надавати підтримку при реєстрації, знаходженні корисної інформації про дозвілля, можливості з’єднати гостей із потрібними людьми у кілька кліків.

4. Internet of Things (IoT). Провідні власники готельного ринку обладнують номера «розумною» технікою. Багато гостей вже використовують елементи «розумного» будинку в своїх квартирах, тому під час подорожей вони бажали би отримати звичний рівень комфорту і в готельних номерах. 3 іншого боку, «розумна» техніка допомагає економити ресурси (воду, електроенергію), а також зняти зі співробітників готелю виконання ряду рутинних завдань.

Наприклад, інфрачервоні датчики дозволяють зрозуміти, коли гості покинули номер - у цей час персонал може прибирати номер. «Розумні» подушки, які оснащені спеціальними волокнами, можуть контролювати тиск, оцінювати стан сну. «Splash of Brilliance»- у перекладі ця технологія отримала назву «запітніле скло душової кабінки». По суті, дверцята душ-кабінки перетворюються на мольберт, завдяки спеціальним сенсорним датчикам. Отже, всі записи та зображення будуть передаватися на планшет, звідки ідеї, що виникли під час приймання душу, можна буде надіслати собі на електронну пошту або месенджер.

5. Сучасна туристична сфера $є$ інформатизованою. Вона має великий потік вхідної інформації, характеризується динамічною зміною цінової політики, пропозицій та кількості наявних місць. На туристичному ринку $є$ певна кількість самостійних туристів, їх число має тенденцію до збільшення. Більшість туристичних фірм надає послугу бронювання турів онлайн, проте потім необхідно йти в офіс для оформлення документації на тур і оплати послуги. Тому сьогодні, у період карантинів, пов'язаних із Covid-19, стає актуальним «Онлайн супермаркет турів», коли споживач може забронювати та придбати будь-яку туристичну послугу на сайті [4].

Бронювання авіаквитків, готелів, трансферів, автомобілів, використовуючи ресурси Інтернету, $\epsilon$ загальнодоступною та звичайною справою для подорожуючих. Придбання туристичної путівки онлайн (без допомоги туристичної агенції) є новою та унікальною послугою.

Будь-який туристичний оператор може представити свої пропозиції. Зовнішній модуль пошуку турів надає можливість вибрати вид туру, країну та регіон для подорожі, дати та тривалість поїздки, рівень готелю чи конкретний готель, місто вильоту, вид харчування, кількість туристів та орієнтовну вартість 
путівки. Такий модуль вже існує на багатьох сайтах туристичних підприємств, однак він розроблений іншим оператором і дає можливість тільки вносити попередню заявку на бронювання, після чого 3 туристом зв'язуються менеджери підприємства та запрошують його в офіс.

Головною відмінністю проєкту «Онлайн супермаркет турів» повинна стати можливість не тільки вносити заявку, а й бронювати та купувати тури самостійно. Якщо людина купує путівку у звичайний спосіб, комісійна винагорода агентства складає у середньому від 10 до 15\% від вартості, але придбання туру в «Онлайн супермаркет турів» дає туристу найвигідніші пропозиції, у цьому випадку комісійна винагорода агентства складатиме від 3 до $5 \%$.

Отже, для туриста придбання туру за допомогою проєкту виглядає так: вибір туру на сайті «Онлайн супермаркет турів», бронювання шляхом внесення паспортних даних, оплата рахунку та отримання необхідних документів для подорожі [4].

Визначимо переваги та недоліки проєкту «Онлайн супермаркет турів», який представляє собою скрипт, вбудований на сайт підприємства (табл. 1).

Таблиия 1

\section{Переваги та недоліки «Онлайн супермаркет турів»}

\begin{tabular}{|c|c|c|}
\hline $\begin{array}{r}\text { Категорія } \\
\text { споживачів }\end{array}$ & Переваги & Недоліки \\
\hline Туристи & $\begin{array}{l}\text { - економія часу; } \\
\text { - здешевлення послуги за рахунок зменшення } \\
\text { агентської винагороди; } \\
\text { • можливість вибору способу оплати. }\end{array}$ & $\begin{array}{l}\text { • відповідальність за правильність } \\
\text { внесення паспортних даних; } \\
\text { • недовіра до нової послуги. }\end{array}$ \\
\hline $\begin{array}{c}\text { Туристичні } \\
\text { агенції }\end{array}$ & $\begin{array}{l}\text { - збільшення рівня продажів; } \\
\text { • відповідальність за правильність } \\
\text { паспортних даних лежить на туристові; } \\
\text { • покращення іміджу підприємства за рахунок } \\
\text { використання сучасних технологій; } \\
\text { • вихід на нові ринки збуту. }\end{array}$ & $\begin{array}{l}\text { • зменшення комісійної винагороди; } \\
\text { • значні першочергові витрати на } \\
\text { рекламу. }\end{array}$ \\
\hline $\begin{array}{c}\text { Туристичні } \\
\text { оператори }\end{array}$ & $\begin{array}{l}\text { - розширення каналів збуту; } \\
\text { - збільшення рівня продажів; } \\
\text { - додаткова реклама. }\end{array}$ & $\begin{array}{l}\text { • необхідність вносити } \\
\text { заявку } 3 \text { попереднюж } \\
\text { анулювання. }\end{array}$ \\
\hline
\end{tabular}

Джерело: складено авторами за матеріалами [8, с. 123; 12]

Отже, цей скрипт дозволяє туристам самостійно підбирати тури, авіаквитки, готелі, трансфери, орендувати автомобілі та оплачувати дані послуги, не виходячи 3 дому. «Онлайн супермаркет турів» сприяє збільшенню обсягів продажів послуг сфери індустрії гостинності та дозволить туристам обрати найнижчі в країні ціни за туристичні послуги.

Аналіз інновацій ресторанного бізнесу, найбільш поширених у країнах Євросоюзу, дає підстави для проведення їх систематизації за видами та визначенні їх складових (рис. 1).

Нововведення у готельному бізнесі виконують чи не головну роль у функціонуванні готелю і залученні споживачів. Для ефективного розвитку готельно-ресторанного бізнесу проводиться пошук нових методів якісного обслуговування, охорони номерів та надання нових послуг для споживачів, які вже впроваджуються в більшості готелів країн Європи та світу. 




Рис. 1. Інновації в індустрії гостинності

Джерело: сформовано авторами на основі опраџьованих джерел [4, 5, 12$]$

Отже, фактично всі інновації готельно-ресторанного бізнесу, незалежно від їх типу, пов'язані з використанням інформаційних технологій та систем обробки інформації для двох основних напрямків:

- ефективного використання ресурсів через економію часу, фінансових та трудових ресурсів;

- збільшення обсягу продажу товарів та послуг через привертання, утримання уваги клієнтів, а також вивчення їх поведінки.

Для порівняльного аналізу важливо виокремити інформаційні технології, які вже сьогодні використовуються у готельно-ресторанному бізнесі України. Стан ресторанного ринку України характеризується нестабільністю та мінливістю.

На підставі вивчення та узагальнення джерел $[4,5,9]$ проведено аналіз інновацій готельно-ресторанного бізнесу України, їх систематизацію за видами та розкрито значення кожного виду (табл. 2).

Таким чином, бізнес індустрії гостинності в Україні пов'язаний із використанням інформаційних та маркетингових технологій, що дозволить:

- ефективно керувати діяльністю закладів через впровадження CRM та хмарних систем автоматизації;

- економити час через бронювання та замовлення онлайн;

- створювати стійкі позитивні враження у клієнтів через організацію шоу дляклієнтів та унікальний дизайн інтер'єру. 
Таблиия 2

Класифікація інновацій у готельно-ресторанному бізнесі України

\begin{tabular}{|c|c|c|}
\hline Вид інновації & Нововведення & Значення \\
\hline \multirow{4}{*}{ Інформаційні } & СRM для доставки їжі & Управління процесом доставки їжі \\
\cline { 2 - 3 } & Well Done & Бронювання столів онлайн \\
\cline { 2 - 3 } & Ultra & Управління діяльністю великих ресторанів \\
\cline { 2 - 3 } & Mister.Am, Eda.ua & Замовлення їжі онлайн \\
\cline { 2 - 3 } & Парус-Готель & Хмарна система автоматизації готелів \\
\cline { 2 - 3 } & PMS Cloud & Хмарний сервіс для управління готелем \\
\cline { 2 - 3 } & Booking.com & Сервіс для бронювання готелів \\
\hline \multirow{3}{*}{ Маркетингові } & Сhow-kitchen & Створення шоу з відкритого процесуприготування \\
\cline { 2 - 3 } & Теппан-шоу & їжі \\
\cline { 2 - 3 } & Унікальний дизайн & Створення WOW- ефекту у клієнтів \\
\hline
\end{tabular}

Джерело: складено авторами на підставі опращьованих джерел [4; 5; 9, с. 138$]$

Однією із умов впровадження діджиталізації в індустрію гостинності $є$ рівень професійної підготовки менеджерів, які забезпечують готовність до використання та впровадження інформаційних технологій. Серед недоліків у підготовці менеджерів для готельного бізнесу працедавці називають невміння здійснювати стратегічне планування, недостатнє знання ринку, основних тенденцій його розвитку, невміння розробляти бізнес-стратегії у довгостроковій перспективі, хибна орієнтація на отримання швидкого прибутку, відсутність якісної інформації про дослідження у сфері готельно-ресторанного бізнесу, некоректна постановка цілей бізнес-проєктів, помилки у термінах реалізації поставлених завдань та інше. Проте, одним із головних недоліків вважаються слабко сформовані навички використання інформаційних технологій. У Звіті Департаменту цифрових технологій, культури, ЗМІ та спорту Великої Британії за 2020 рік наведено результати інтернет-опитування в рамках дослідницького проєкту «Персонал у сфері гостинності та туризму», у якому зазначено результати опитування фахівців, які працюють в індустрії гостинності, щодо важливості професійних та соціальних компетентностей. Серед технічних навичок, необхідних для виконання професійної діяльності, респонденти на перші позиції поставили «потужні знання в галузі» - 33\%; «комп'ютерна грамотність / базові IT-навички» - 30\% [13].

В умовах жорсткої конкуренції рівень готовності кадрового потенціалу до впровадження інновацій має виключне значення для стабільності і розвитку індустрії гостинності.

За результатами дослідження, проведеного журналом CEOWORLD за 2020 рік, визначено 10 найкращих шкіл гостинності та готельного господарства у світі (табл. 3).

Серед країн із найбільш престижними закладами, де готують фахівців для готельно-ресторанного бізнесу, перше місце займає Швейцарія. Саме випускники швейцарських навчальних закладів можуть гарантовано отримати роботу. Причина полягає у тому, що у Швейцарії туризм є однією з історично трендових галузей економіки, обслуговування якого, у першу чергу, й забезпечується готельно-ресторанним бізнесом. 
Топ-10 найкращих шкіл гостинності у світі у 2020 році

\begin{tabular}{|c|c|}
\hline $\begin{array}{l}\text { Позиція у } \\
\text { рейтингу }\end{array}$ & Назва закладу (країна) \\
\hline 1 & Ecole Hoteliere de Lausanne (Швейцарія) \\
\hline 2 & Школа готельного менеджменту, Корнельський університет (США) \\
\hline 3 & $\begin{array}{l}\text { Оксфордська школа управління гостинністю (Оксфордський університет Брукс) } \\
\text { (Велика Британія) }\end{array}$ \\
\hline 4 & Готельна школа Гаага (Нідерланди) \\
\hline 5 & Коледж Конрада Н. Хілтона, Університет Х’юстона (США) \\
\hline 6 & Школа готельного бізнесу, Мічиганський державний університет (США) \\
\hline 8 & Пенсильванський державний університет (США) \\
\hline 9 & $\begin{array}{l}\text { Кафедра управління гостинності та туризму, Ізенберзька школа менеджменту, } \\
\text { Університет Массачусетса Амхерст (США) }\end{array}$ \\
\hline 10 & Міжнародна школа готельного управління Les Roches (Швейцарія) \\
\hline
\end{tabular}

Характерною рисою освітніх програм у більшості університетів країн Євросоюзу, які готують фахівців для індустрії гостинності, $є$ наявність факультативних курсів, які відповідають галузі, а також робота над реальними проєктами бізнес-консалтингу або прикладними науковими проєктами 3 обов'язковим використанням інформаційних технологій.

Більшість програм із готельно-ресторанного бізнесу у Швейцарії містять однаковий об'єм теорії і практики. Зазвичай це 2 семестри, один 3 яких має за мету набуття практичного досвіду у діючих готелях або ресторанах, а другий отримання теоретичних знань, які набуваються в умовах, наближених до реальної професійної діяльності. Університети готельно-ресторанного бізнесу у Швейцарії надзвичайно ретельно відбирають компанії та корпорації для стажування студентів. Перевага надається провідним компаніям. Зокрема, це готелі Four Seasons, Hilton, Hyatt, брендові потенційні працедавці: Disneyland, Ritz-Carlton та інші, які вирізняються високим рівнем інновацій в обслуговуванні клієнтів. Орієнтованість на практичний досвід провідних працедавців із поєднанням високотехнологічних університетських середовищ забезпечують високу конкурентоспроможність на світовому ринку праці випускникам університетів Швейцарії.

Висновки. Проведений аналіз міжнародного (зокрема, європейського) та національного розвитку індустрії гостинності дозволяє зробити наступні висновки.

Відносини між виробником і споживачем, рівень кваліфікації кадрів, їхніх творчих можливостей, уміння освоювати нові технології й організаційні форми, створювати середовище гостинності $\epsilon$ головними передумовами розвитку готельного та ресторанного бізнесу в Україні. Перспективами такого розвитку $\epsilon$ прогнозована здатність стабільного розвитку, забезпечення робочими місцями великої кількості громадян, позитивний вплив на економіку держави.

Технологічний прогрес у галузі штучного інтелекту протягом наступних кількох років принесе новий рівень цифрової трансформації для тих, хто інвестує в інновації. 
Інновації індустрії гостинності країн Європи пов'язані з використанням інформаційних технологій, систем управління та обробки інформації. Це дозволяє раціонально використовувати фінансові, людські, матеріальні ресурси, підвищувати комфорт та зручність клієнтів та економити їх час.

Рекомендаціями для українських університетів 3 підготовки фахівців гостинного бізнесу є: забезпечення інтеграції теоретичного та практичного навчання, тривале щорічне стажування студентів у провідних готелях України та за кордоном, створення додаткових умов для формування навичок роботи 3 інформаційними технологіями, орієнтація викладачів університетів на створення високотехнологічних університетських середовищ, що забезпечують готовність випускника університету до інновацій у гостинному бізнесі.

\section{Список використаних джерел}

1. Гончарук Т.В. Зарубіжний досвід розвитку підприємницьких структур та можливості його використання в Україні. Ефективна економіка. 2017. № 9. URL: http://www.economy.nayka.com.ua/?op=1\&z=5772 (дата звернення 20.01.2021)

2. Гросул В.А., Калєнік А.В. Особливості формування конкурентної стратегії підприємства ресторанного господарства. Інноваційний потениіал сучасної економічної науки: матеріали Міжнародної науково-практичної інтернет-конференції економічного спрямування. Тернопіль. 2017. С. 13-15. URL: http://www.economy-confer.com.ua/full-article/2336/ (дата звернення: 26.01.2021).

3. Дишкантюк О.В. Теоретичні основи функціонування індустрії гостинності. Економіка: реалії часу. 2015. № 6 (22). C. 96-101. URL: http://economics.opu.ua /files/archive/2015/n6.html (дата звернення: 20.02.2021).

4. Інноваційні технології в готельному бізнесі. URL: http://www.rusnauka.com/6_PNI_2014/Informatica/3_160394.doc.htm (дата звернення: 12.04.2021).

5. Кузьменко А.В., Третяк Ю.І. Впровадження Інтернет-маркетингу для просування продукції підприємства (на прикладі ТОВ «Барин»). Економіка та суспільство. 2018. № 16. URL: http://economyandsociety. in.ua/journal/16_ukr/59. pdf (дата звернення: 15.01.2021).

6. Нездоймінов С.Г., Дишловий I.M. Науково-методологічні засади формування стратегії конкурентоспроможності готельних підприємств регіону. Бізнес Інформ. 2011. № 6. С 145-149.

7. П’ятницька Г.Т., Найдюк В.С. Сучасні тренди розвитку ресторанного господарства в Україні. Економіка та держава. 2017. № 9. С. 66-73.

8. Перерва П.Г., Косенко А.В., Маслак М.В., Матросова В.О., Долина І.В. Розвиток організаційно-економічного механізму управління розвитком індустрії туризму та гостинності. Вісник НТУ «ХПI» Серія: Економічні науки. 2018. № 48 (1324). С. 121-127.

9. Попик М.М. Професійна підготовка фахівців готельно-ресторанної справи: досвід Швейцарії. Науковий вісник Ужггородського університету. 
Серія: «Педагогіка. Соиіальна робота». 2019. Вип. 1 (44). С. 137-139. DOI: https://doi.org/10.24144/2524-0609.2019.44.137-140.

10. Ставська Ю.В. Особливості та зміст інновацій у сфері гостинності. Економіка, фінанси, менеджмент: актуальні питання науки і практики. 2018. № 3 (31). С. 35-46.

11. Табенська O.I. Сучасні тенденції розвитку індустрії гостинності в Німеччині. Науковий вісник Ужгородського наиіонального університету. Серія «Міжнародні економічні відносини та світове господарство». 2020. Вип. 34. C. 185-190. DOI: https://doi.org/10.32782/2413-9971/2020-34-31.

12. Юрчук Н.П. Інформаційні системи і технології як інновація у системі управління бізнес-процесами. Ефективна економіка. 2018. № 5. URL: http://ojs.dsau.dp.ua/index.php/efektyvna-ekonomika/article/view/1235

(дата звернення: 29.03.2021).

13. Hospitality and Tourism workforce landscape. URL: https://assets. publishing.service.gov.uk/government/uploads/system/uploads/attachment_data/file/8 27952/Hospitality_and_Tourism_Workforce_Landscape.pdf (дата звернення: 26.03.2021).

\section{References}

1. Honcharuk, T.V. (2017). Zarubizhnyj dosvid rozvytku pidpryjemnycjkykh struktur ta mozhlyvosti jogho vykorystannja v Ukrajini [The foreign experience in the development of business structures and the possibility of its use in Ukraine]. Efektyvna ekonomika - Efficient economy, 9. Retrieved from: http: //www. economy. nayka.com.ua/?op=1\&z=5772 [in Ukranian].

2. Hrosul, V.A., \& Kaljenik, A.V. (2017). Osoblyvosti formuvannja konkurentnoji strateghiji pidpryjemstva restorannogho ghospodarstva [Features of formation of competitive strategy of the restaurant enterprise]. Mizhnarodna naukovo-praktychna internet-konferentsiia ekonomichnoho spriamuvannia "Innovatsiinyi potentsial suchasnoi ekonomichnoi nauky» - International scientificpractical Internet conference of economic direction "Innovative potential of modern economics». (pp. 13-15). Ternopilj. Retrieved from: http://www. economyconfer.com.ua/full-article/2336/ [in Ukranian].

3. Dyshkantyuk O.V. (2015). Teoretychni osnovy funktsionuvannya industriyi hostynnosti [Theoretical foundations of the hospitality industry]. Ekonomika: realiyi chasu - Economics: the realities of time, 6 (22), 96-101. Retrieved from: http://economics.opu.ua /files/archive/2015/n6.html [in Ukrainian].

4. Innovatsiyni tekhnolohiyi $\mathrm{v}$ hotel'omu biznesi [Investment technologies in the hotel business]. rusnauka.com. Retrieved from: http://www.rusnauka.com/6 _PNI_2014 /Informatica/3_160394.doc.htm [in Ukrainian].

5. Kuzjmenko, A.V., \& Tretjak, Ju.I. (2018). Vprovadzhennia Internetmarketynhu dlia prosuvannia produktsii pidpryiemstva (na prykladi TOV «Baryn») [The introduction of Internet marketing to promote the companys products (for example, LLC «Barin»)]. Ekonomika ta suspilstvo - Economy and society, 16. Retrieved from: http://economyandsociety.in.ua/journal/16_ukr/59.pdf [in Ukranian]. 
6. Nezdoiminov, S.H., \& Dyshlovyi, I.M. (2011). Naukovo-metodolohichni zasady formuvannia stratehii konkurentospromozhnosti hotelnykh pidpryiemstv rehionu [Scientific-methodological ambush of the formulation of the strategy of competitiveness of hotel production in the region]. Biznes Inform - Business Inform, 6, 145-149 [in Ukrainian].

7. Pyatnytska, H.T., \& Naydyuk, V.S. (2017). Suchasni trendy rozvytku restorannoho hospodarstva $\mathrm{v}$ Ukrayini [Modern trends in the development of the restaurant industry in Ukraine]. Ekonomika ta derzhava - Economy and state, 9, 6673 [in Ukrainian].

8. Pererva, P.H., Kosenko, A.V., Maslak, M.V., Matrosova, V.O., \& Dolyna, I.V. (2018). Rozvytok orhanizatsiyno-ekonomichnoho mekhanizmu upravlinnya rozvytkom industriyi turyzmu ta hostynnosti [Development of organizational and economic mechanism for managing the development of the tourism and hospitality industry]. Visnyk NTU «KHPI» Seriya: Ekonomichni nauky Bulletin of NTU «KhPI» Series: Economic Sciences, 48 (1324), 121-127 [in Ukrainian].

9. Popyk, M.M. (2019). Profesiyna pidhotovka fakhivtsiv hotel'norestorannoyi spravy: dosvid Shveytsariyi [Professional training of hotel and restaurant specialists: the experience of Switzerland]. Naukovyy visnyk Uzhhorods'koho universytetu. Seriya: «Pedahohika. Sotsial'na robota»-Scientific Bulletin of Uzhhorod University. Series: «Pedagogy. Social work», 1 (44), 137-139 [in Ukrainian].

10. Stavska, Yu.V. (2018). Osoblyvosti ta zmist innovatsiy u sferi hostynnosti. [Features and content of innovations in the field of hospitality]. Ekonomika, finansy, menedzhment: aktual'ni pytannya nauky i praktyky - Economics, finance, management: topical issues of science and practice activity, 3 (31), 35-46 [in Ukrainian].

11. Tabenska, O.I. (2020). Suchasni tendentsiyi rozvytku industriyi hostynnosti $\mathrm{v}$ Nimechchyni [Modern trends in the hospitality industry in Germany]. Naukovyy visnyk Uzhhorods'koho universytetu. Seriya «Mizhnarodni ekonomichni vidnosyny ta svitove hospodarstvo» - Scientific Bulletin of Uzhhorod National University. Series «International Economic Relations and the World Economy», 34, 185-190 [in Ukrainian].

12. Yurchuk, N.P. (2018). Informatsiyni systemy i tekhnolohiyi yak innovatsiya u systemi upravlinnya biznes-protsesamy [Information systems and technologies as an innovation in the business process management system]. Efektyvna ekonomika - Efficient economy, 5, 56. Retrieved from: http://ojs.dsau.dp.ua/index.php/efektyvna-ekonomika/article/view/1235 Ukrainian].

13. Hospitality and Tourism workforce landscape. assets.publishing.service.gov.uk. Retrieved from: https: //assets.publishing.service.gov.uk/government/uploads/system/uploads/attachment_d ata/file/827952/Hospitality_and_Tourism_Workforce_Landscape.pdf [in Ukrainian]. 


\section{Відомості про авторів}

ДжЕДжУЛА Олена Михайлівна - доктор педагогічних наук, професор, завідувачка кафедри математики, фізики та комп'ютерних технологій, Вінницький національний аграрний університет (21008, м. Вінниця, вул. Сонячна, 3, e-mail: DzhedzhulaO@ukr.net).

ВОЛОНТИР Людмила Олексіївна - кандидат технічних наук, доцент кафедри комп'ютерних наук та економічної кібернетики, Вінницький національний аграрний університет (21008, м. Вінниця, вул. Сонячна, 3, e-mail: milavolontyr@ukr.net)

DZHEDZHULA Olena - Doctor of Pedagogical Sciences, Professor, Head of the Department of Mathematics, Physics and Computer Technologies, Vinnytsia National Agrarian University (21008, Vinnytsia, 3, Soniachna Str., e-mail: DzhedzhulaO@ukr.net).

VOLONTYR Lyudmyla - Candidate of Technical Sciences, Associate Professor of the Department of Computer Science and Economic Cybernetics, Vinnytsia National Agrarian University (21008, Vinnytsia, 3, Soniachna Str., e-mail: milavolontyr@ukr.net).

ДЖЕДЖУЛА Елена Михайловна - доктор педагогических наук, профессор, заведующая кафедрой математики, физики и компьютерных технологий, Винницкий национальный аграрный университет (21008, г. Винница, ул. Солнечная, 3, e-mail: DzhedzhulaO@ukr.net).

ВОЛОНТЫР Людмила Алексеевна - кандидат технических наук, доцент кафедры компьютерных наук и экономической кибернетики, Винницкий национальный аграрный университет (21008, г. Винница, ул. Солнечная, 3, e-mail: milavolontyr@ukr.net). 